\title{
EVALUASI TREND KUALITAS PENDIDIKAN DI INDONESIA
}

\author{
Sabar Budi Raharjo \\ Balitbang Kemendiknas \\ raharjo2sbr@yahoo.co.id
}

\begin{abstract}
Abstrak
Penelitian ini dilakukan dengan tujuan untuk memperoleh informasi tentang tanggapan dan kelayakan satuan pendidikan terhadap penerapan delapan standar nasional pendidikan (SNP), trend kuantitas dan kualitas pendidikan, status akreditasi sekolah, tingkat pemenuhan, rasional dan tanggapan terhadap SNP, urutan delapan standar nasional yang harus dicapai, standar nasional yang paling sulit dicapai, tingkat kepuasan peserta didik terhadap pelayanan sekolah dan hambatan-hambatan dalam mencapai SNP. Metode penelitian yang digunakan adalah dengan Focus Group Discussion (FGD) dan studi dokumentasi. Data hasil FGD dianalisis secara kualitatif dan data hasil mengedarkan instrument dianalisis secara kuantitatif. Hasil penelitian menunjukkan bahwa, setiap satuan pendidikan memberi tanggapan yang positif dan layak untuk menerapkan standar nasional pendidikan. Kualitas lulusan dan persentase lulusan cenderung naik. Jumlah sekolah yang terakreditasi yang terbanyak adalah nilai B, dengan tingkat pemenuhan delapan standar nasional untuk SD 73,55\%, SMP 85,97\%, SMA 77,07\% dan SMK 76,15\%. SNP yang sulit dicapai adalah standar kompetensi lulusan, ketenagaan, sarana dan prasarana. Variabel standar isi, ketenagaan, sarana dan prasarana, pembiayaan, pengelolaan, penilaian, mempunyai hubungan yang positif yang besarnya bervariasi terhadap variabel standar proses dan komptensi lulusan. Kualitas pelayanan untuk SD telah mencapai 87,4\%, SMP 82,6\%, Urutan prioritas dalam meningkatkan kompetensi lulusan, dilakukan dengan meningkatkan kualitas standar ketenagaan, isi, sarana dan prasarana, pengelolaan, penilaian, proses dan pembiayaan meskipun terdapat berbagai hambatan yang dialami sekolah.
\end{abstract}

Kata kunci: trend, kualitas, standar nasional 
Jurnal Penelitian dan Evaluasi Pendidikan

\title{
QUALITY EVALUATION OF EDUCATION TREND IN INDONESIA
}

\author{
Sabar Budi Raharjo \\ Balitbang Kemendiknas \\ raharjo2sbr@yahoo.co.id
}

\begin{abstract}
The research aims to obtain information about the response and the feasibility of education unit to the application in eight national standards, the trend of the quantity and quality of education, school accreditation status, the level of compliance with national education standards, and rational responses to the eight national standard, a sequence of eight national standards that should be achieved, the national standard that is difficult to achieve, the level of student satisfaction with the school service and obstacles in achieving national education standards. The research method used was a Focus Group Discussion (FGD) and documentation. FGD data were analyzed qualitatively and distributed instrument data results were analyzed quantitatively.The results showed every educational unit responses positively and appropriately to implement national education standards. Quality and percentage of graduates tend to increase, but still in the range of values 7.1. The percentage of graduates tends to grow up close to $99 \%$. The number of accredited schools is mostly in B. The level of compliance of eight national standards for SD is $73.55 \%$, Junior high school is $85.97 \%$, SMA is $77.07 \%$, and SMK is $76.15 \%$. National education standards which are difficult to achieve are competency standards, workforce, facilities and infrastructure. Variable content standards, energy, infrastructure, finance, management, and appraisal have positive relation whose the amount varies with the standard variable process and competency of graduates. Service quality for primary schools has reached $87.4 \%$, and junior high schools reached $82.6 \%$. The priority to improve graduate competency was done through improving standard of content, facilities, management, assessment, process, and budgeting in spite of many obstacles faced by schools.
\end{abstract}

Keywords: trend, quality, national standard

512 - Jurnal Penelitian dan Evaluasi Pendidikan Tahun 16, Nomor 2, 2012 


\section{Pendahuluan}

Telah menjadi keyakinan semua bangsa di dunia, bahwa pendidikan mempunyai peran yang sangat besar dalam kemajuan bangsa. Suyanto (2003) menyatakan bahwa seorang presiden negara paling maju di dunia, masih tetap mengakui bahwa investasi dalam pendidikan merupakan hal yang penting dalam kemajuan bangsa. "As a nation, we now invest more in education than in defense". Oleh sebab itu, di era global seperti saat ini, manakala suatu pemerintahan tidak memperdulikan pembangunan sektor pendidikan secara serius dan berkelanjutan, mudah diprediksi bahwa pemerintahan negara itu dalam jangka panjang justru akan menjebak mayoritas rakyatnya memasuki dunia keterbelakangan dalam berbagai aspek kehidupan (Suyanto, 2000: 3).

Pemerintah Republik Indonesia dalam membangun pendidikan di Indonesia berpegang pada salah tujuan bangsa Indonesia yang tertera dalam pembukaan Undang-undang Dasar 1945 alenia ke empat yaitu mencerdaskan kehidupan bangsa. Sejalan dengan tujuan yang tertera dalam Pembukaan Undang-Undang Dasar 1945 tersebut, dalam batang tubuh konstitusi itu diantaranya Pasal 20, Pasal 21, Pasal 28 C ayat (1), Pasal 31 dan Pasal 32, juga mengamanatkan, bahwa pemerintah mengusahakan dan menyelenggarakan satu sistem pendidikan nasional. Sistem pendidikan nasional yang terbaru ini diwujudkan dalam Undang-undang No 20 tahun 2003 tentang Sistem Pendidikan Nasional. Sistem pendidikan nasional adalah keseluruhan komponen pendidikan yang saling terkait secara terpadu untuk mencapai tujuan pendidikan nasional.

Dalam undang-undang no 20 tentang sistem pendidikan Nasional tersebut dinyatakan bahwa "Pendidikan adalah usaha sadar dan terencana untuk mewujudkan suasana belajar dan proses pembelajaran agar peserta didik secara aktif mengembangkan potensi dirinya untuk memiliki kekuatan spiritual keagamaan, pengendalian diri, kepribadian, kecerdasan, akhlak mulia, serta ketrampilan yang diperlukan dirinya, masyarakat, bangsa dan Negara”. Berdasarkan pengertian tersebut dapat dipahami bahwa pendidikan itu harus disadari arti pentingnya, dan direncanakan secara sistematis, agar suasana belajar dan proses pembelajaran berjalan secara 
optimal. Dengan terbentuknya suasana dan proses pembelajaran tersebut, peserta didik akan aktif mengembangkan potensi sesuai dengan bakat dan minatnya. Dengan berkembangnya potensi peserta didik, maka mereka akan memiliki kekuatan spiritual keagamaan, pengendalian diri, kepribadian, kecerdasan, akhlak mulia, serta ketrampilan yang diperlukan dirinya, masyarakat, bangsa dan Negara.

Pendidikan di Indonesia diselenggarakan melalui jalur, jenjang dan jenis pendidikan. Jalur pendidikan adalah wahana yang dilalui peserta didik untuk mengembangkan potensi dirinya dalam suatu proses pendidikan yang sesuai dengan tujuan pendidikan. Terdapat tiga jalur pendidikan yaitu, jalur pendidikan formal, nonformal dan informal. Pendidikan formal adalah jalur pendidikan yang terstruktur dan berjenjang yang terdiri atas pendidikan dasar, pendidikan menengah dan pendidikan tinggi. Pendidikan nonformal adalah jalur pendidikan di luar pendidikan formal yang dapat dilaksanakan secara terstruktur dan berjenjang. Pendidikan informal adalah jalur pendidikan keluarga dan lingkungan.

Pemerintah selalu berupaya untuk meningkatkan kualitas pendidikan melalui berbagai kebijakan, antara lain kebijakan sertifikasi guru dan dosen, bantuan operasional sekolah, pemberian block grant dan menetapkan standar nasional yang dituangkan dalam PP No. 19 tahun 2005 tentang Standar Nasional Pendidikan. Standar pendidikan meliputi standar isi, proses, ketenagaan, sarana dan prasarana, pengelolaan, evaluasi, pembiayaan dan kompetensi lulusan.

Dengan adanya standar nasional tersebut, maka arah peningkatan kualitas pendidikan Indonesia menjadi lebih jelas. Bila setiap satuan pendidikan telah dapat mencapai atau melebihi standar nasional pendidikan tersebut, maka kualitas satuan pendidikan tersebut dapat dinyatakan tinggi. Berbagai kebijakan yang mendorong peningkatan kualitas pendidikan telah ditetapkan dan diimplementasikan, dengan harapan kualitas pendidikan dapat berangsur-angsur meningkat pada gradasi yang tinggi. Berkenaan dengan hal tersebut, maka pada kesempatan ini akan dievaluasi bagaimana trend perkembangan kualitas pendidikan di Indonesia, sebagai akibat adanya kebijakan-kebijakan tersebut. Karena SNP telah ditetapkan pada tahun 2005 dan telah diimplementasikan, maka evaluasi kualitas pendidikan akan 
didasarkan pada SNP. Dewasa ini mutu bukan hanya menjadi masalah dan kepedulian dalam bidang bisnis, melainkan juga di bidang-bidang lainnya. Seperti pemerintahan, pelayanan sosial, pendidikan bahkan bidang keamanan dan ketertiban (Nana Syaodih, dkk 2006)

Goetsch and Davis (2006) memberikan definisi tentang kualitas adalah sebagai berikut. "Quality is dynamic state associate with product, service, people, process, and environments that metts or exceeds expectations". Kualitas merupakan pernyataan yang dinamis yang terkait dengan produk, pelayanan, orang, proses dan lingkungan yang dapat memenuhi atau melebihi yang diharapkan.

Selanjutnya Ishikawa (2006) mendefinisikan kualitas sebagai berikut. (a) quality and customer satisfaction are the same things and (b) quality is a broad concept that goes beyond just product quality to also include the quality of people, processes, and every other aspect of the organization. Artinya kualitas memiliki dua dimensi yaitu: (a) kualitas dan kepuasan pelanggan merupakan hal yang sama, karena bila pelanggan mendapatkan kualitas barang atau jasa, maka akan memperoleh kepuasan. (b) Kualitas merupakan konsep yang luas yang bukan hanya kualitas produk, tetapi juga kualitas orang, proses kerja, dan setiap aspek dari organisasi.

Peraturan No 19 tahun 2005 tersebut dinyatakan bahwa, Standar nasional pendidikan memuat kriteria minimal tentang komponen pendidikan yang memungkinkan setiap jenjang dan jalur pendidikan untuk mengembangkan pendidikan secara optimal sesuai dengan karakteristik dan kekhasan programnya. Standar nasional pendidikan tinggi diatur seminimal mungkin untuk memberikan keleluasaan kepada masing-masing satuan pendidikan pada jenjang pendidikan tinggi dalam mengembangkan mutu layanan pendidikannya sesuai dengan program studi dan keahlian dalam kerangka otonomi perguruan tinggi. Demikian juga standar nasional pendidikan untuk jalur pendidikan nonformal hanya mengatur hal-hal pokok dengan maksud memberikan keleluasaan kepada masing-masing satuan pendidikan pada jalur pendidikan nonformal yang memiliki karakteristik tidak terstruktur untuk mengembangkan programnya sesuai dengan kebutuhan masyarakat.Penyelenggaraan pendidikan jalur informal yang sepenuhnya menjadi kewenangan keluarga dan masyarakat didorong 
dan diberikan keleluasaan dalam mengembangkan program pendidikannya sesuai dengan kebutuhan keluarga dan masyarakat. Oleh karena itu, standar nasional pendidikan pada jalur pendidikan informal hanya mengatur hal-hal yang berkaitan dengan pengakuan kompetensi peserta didik saja.

Sebagaimana tertuang dalam PP 19 Tahun 2005 terdapat Delapan Standar Nasional Pendidikan sebagaimana tertuang dalam Pasal 2 Ayat (1), yaitu meliputi, standar kompetensi lulusan, standar isi, standar proses, standar pendidikan dan tenaga kependidikan, standar sarana dan prasarana, standar pengelolaan, standar pembiayaan dan standar penilaian. Pengertian masing-masing standar adalah sebagai berikut. Delapan Standar Nasional Pendidikan tersebut dalam penelitian ini selanjutnya dijadikan dimensi variabel trend kualitas pendidikan.

\section{Metode Penelitian}

Untuk menjawab rumusan tentang kelayakan satuan pendidikan, tingkat pemenuhan delapan standar, hubungan antar standar nasional, kepuasan pelayanan, urutan skala prioritas, dan standar nasional yang paling sulit dicapai, digunakan metode survei. Untuk menjawab rumusan masalah tentang trend kuantitas lulusan, trend kualitas lulusan, dan kinerja sekolah yang diukur dari status akreditasi sekolah digunakan metode dokumentasi, dan untuk menjawab rumusan masalah tentang, rasional standar nasional dikelompokkan menjadi delapan standar, hambatan dan upaya untuk pemenuhan standar nasional bagi tiap satuan pendidikan, digunakan metode diskusi terfokus (Focus Group Discussion/FGD) dengan para kepala sekolah.

Penelitian dengan metode survei dilakukan pada populasi dan sampel. Populasi dalam penelitian ini adalah seluruh SMP N yang tersebar di seluruh Indonesia, yaitu 16803 SMP N. Karena terlalu luasnya populasi sekolah dan keterbatasan dana, maka penelitian menggunakan sampel yang diambil secara stratified random sampling dengan berdasarkan tingkat kesalahan (sampling error) 5\%. sehingga jumlah sample 42 SMP N Selanjutnya kegiatan FDG setiap provinsi dilakukan dengan 15 orang nara sumber, terdiri atas unsur dinas pendidikan, pakar dan kepala sekolah. 
Teknik pengumpulan data yang digunakan dalam penelitian ini adalah dengan memberikan kuesioner kepada kepala sekolah yang terpilih sebagai sampel, dokumentasi nilai ujian nasional sejak tahun 2005 sampai dengan 2009 yang ada di Puspendik, dokumentasi akreditasi sekolah yang ada di Badan Akreditasi Sekolah, dan Focus Group Discussion (FGD) dengan kepala sekolah.

Untuk memperoleh data tentang tingkat kelayakan sekolah dalam mencapai delapan standar, tingkat pemenuhan standar nasional tiap satuan pendidikan, hubungan variabel antar standar nasional, dan kepuasan pelayanan digunakan instrumen yang dikembangkan berdasarkan delapan standar nasional pendidikan dan kepuasan pelayanan. Instrumen tersebut telah teruji validitas dan reliabilitasnya. Selanjutnya untuk memperoleh data tentang trend kuantitas dan kualitas pendidikan digunakan lembar isian, dan untuk memperoleh data rasional penggunaan standar nasional pendidikan, hambatan dan upaya mengatasi dalam pemenuhan standar nasional digunakan panduan diskusi

Untuk menjawab rumusan masalah tentang tingkat kelayakan sekolah, trend kuantitas dan kualitas lulusan, tingkat pemenuhan standar nasional tiap satuan pendidikan, hubungan variabel antar standar nasional, dan kepuasan pelayanan, analisis data menggunakan statistik deskriptif yang berupa perhitungan rata-rata, persentase dan analisis korelasi. Selanjutnya data hasil diskusi dianalisis secara kualitatif, dengan langkahlangkah data collection, data reduction, data display dan verification

\section{Hasil Penelitian dan Pembahasan}

Hasil analisis mengenai kelayakan Sekolah Menengah Pertama dalam mencapai SNP disajikan pada Tabel 1.

Tabel 1. Persentase SMP Dalam Mencapai Standar Nasional Pendidikan

\begin{tabular}{|l|c|c|c|c|c|}
\hline \multirow{2}{*}{$\begin{array}{l}\text { Jenjang } \\
\text { Sekolah }\end{array}$} & \multicolumn{5}{|c|}{ Persentase Pencapaian } \\
\cline { 2 - 6 } & $50-60 \%$ & $>60-70 \%$ & $>70-80 \%$ & $>80 \%$ & Jmlh (\%) \\
\hline SMP & $0 \%$ & $0 \%$ & $12 \%$ & $88 \%$ & $100 \%$ \\
\hline
\end{tabular}


Berdasarkan Tabel 1 tersebut terlihat bahwa $12 \%$ SMP telah layak mencapai standar nasional $70,1-80 \%$, yaitu SMP mencapai pemenuhan 88\% SNP. Jumlah persentase tersebut merupakan gambaran bahwa satuan pendidikan sudah layak mencapai standar nasional pendidikan yang dipengaruhi oleh status akreditasi sekolah. Semakin tinggi status akreditasi sekolah maka semakin tinggi pencapaian standar nasional pendidikan.

Trend Kuantitas dan Kualitas Pendidikan disajikan pada Tabel 2.

Tabel 2. Perkembangan Persentase Kelulusan Dan Nilai Ujian Nasional Tahun 2006 - 2010

\begin{tabular}{|l|c|c|c|c|c|c|c|c|c|c|}
\hline \multirow{2}{*}{ Jenjang } & \multicolumn{2}{|c|}{2006} & \multicolumn{2}{c|}{2007} & \multicolumn{2}{c|}{2008} & \multicolumn{2}{c|}{2009} & \multicolumn{2}{c|}{2010} \\
\cline { 2 - 10 } & $\begin{array}{c}\% \\
\text { Lulus }\end{array}$ & Nilai & $\begin{array}{c}\% \\
\text { Lulus }\end{array}$ & Nilai & $\begin{array}{c}\% \\
\text { Lulus }\end{array}$ & Nilai & $\begin{array}{c}\% \\
\text { Lulus }\end{array}$ & Nilai & $\begin{array}{c}\% \\
\text { Lulus }\end{array}$ & Nilai \\
\hline $\begin{array}{l}\text { SMP/MTs } \\
\text { /SMPT }\end{array}$ & 92,1 & 7,03 & 93,34 & 6,98 & 92,76 & 6,87 & 95,09 & 7,35 & 99,42 & 7,37 \\
\hline
\end{tabular}

Berdasarkan Tabel 2 tersebut, kuantitas pendidikan diukur berdasarkan persentase lulusan bahwa, rata-rata persentase lulusan nasional untuk SMP/MTs pada tahun 2006 sebesar 92,1\%, tahun 2007 sebesar 93,34\%; tahun 2008 sebesar $92,76 \%$; tahun 2009 sebesar $95,09 \%$ dan tahun 2010 sebesar $99,42 \%$.

Pada jenjang SMP/MTs/SMPT, jumlah kelulusan meningkat 2,33\% dari tahun 2008 sedangkan pada tahun 2010 jumlah kelulusan meningkat 4,33\% dari tahun 2009. Jumlah kelulusan tahun 2011 diharapkan dapat bertahan pada posisi 99,5\% karena jumlah tersebut sudah mendekati jumlah maksimum 100\% yang mungkin sulit untuk dicapai.

Peningkatan dan penurunan persentase jumlah kelulusan antara lain dipengaruhi oleh kebijakan penentuan kelulusan. Pada tahun 2008, kelulusan ditetapkan dengan standar nilai Ujian Nasional (UN) pada tiga mata pelajaran. Pada saat itu, pemerintah menetapkan kebijakan UNPK (Ujian Nasional Pendidikan Kesetaraan) untuk mengatasi siswa yang tidak lulus. Siswa yang tidak lulus UN dan mengikuti UNPK secara otomatis tidak akan mendapat surat kelulusan dari sekolah melainkan mendapat surat kelulusan dari lembaga pendidikan non formal seperti kelompok 
belajar Paket A, Paket B dan Paket C. Dengan berbagai kekurangan ini, setiap tahun pemerintah memperbaki kebijakannya. Pada tahun 2010, siswa yang belum lulus UN masih diberi kesempatan untuk mengikuti ujian nasional ulangan sehingga jumlah kelulusan semakin meningkat.

Selanjutnya bila dilihat dari kualitas pendidikan yang didasarkan pada rata-rata nilai ujian nasional dapat dikemukakan sebagai berikut. Nilai ratarata ujian nasional untuk SMP/MTs/SMPT tahun 2006 sebesar 7,03; tahun 2007 sebesar 6,98; tahun 2008 sebesar 6,87; tahun 2009 sebesar 7,35 dan tahun 2010 sebesar 7,37.

Trend kualitas lulusan menurut nilai rerata UN menunjukkan kisaran nilai yang relatif tetap berada di sekitar nilai 7 . Nilai rerata UN $\mathrm{SMP} / \mathrm{MTs}$ /SMPT tidak menunjukkan trend khusus, namun ada kecenderungan yang sama yaitu setelah rerata nilai UN mengalami penurunan pada tahun 2008, kemudian pada tahun berikutnya langsung melonjak naik sebesar 0,5 point dan menetap pada posisi tersebut pada tahun 2010. Berdasarkan trend ini dapat dianalisis bahwa nilai rerata UN mampu memacu semangat sekolah, yaitu ketika nilai rerata UN turun, sekolah kemudian berjuang keras untuk meningkatkannya pada tahun berikutnya. Demikian juga bagi perancang soal tes UN, ketika hasil tes memiliki tingkat kesulitan yang tinggi dan skor/nilai yang dapat dicapai rendah/turun, maka tahun berikutnya soal tes lebih dipermudah, supaya siswa dapat mencapai skor/nilai yang lebih tinggi.

Status Akreditasi Sekolah disajikan pada Tabel 3.

Tabel 3. Perkembangan Status Akreditasi SMP berdasarkan Jumlah yang Mengusulkan

\begin{tabular}{|c|c|c|c|}
\hline \multirow{2}{*}{ Akreditasi } & \multicolumn{3}{|c|}{ Nilai Akreditasi SMP } \\
\cline { 2 - 4 } & Tahun 2007 & Tahun 2008 & Tahun 2009 \\
\hline A & 868 & 959 & 1548 \\
\hline B & 2412 & 1306 & 1438 \\
\hline C & 1590 & 707 & 579 \\
\hline TT & 439 & 143 & 158 \\
\hline
\end{tabular}


Berdasarkan Tabel 3 tersebut terlihat bahwa jumlah SMP yang terakreditasi A tahun 2007 sebesar 868, tahun 2008 sebesar 959 dan tahun 2009 sebesar 1856. Jumlah yang terakreditasi B lebih banyak daripada A, dan yang yang terakreditasi $C$ lebih sedikit daripada $A$.

Pada jenjang SMP terjadi fenomena sekolah yang mengajukan akreditasi tetapi masih belum terakreditasi atau hanya mendapat akreditasi C berjumlah lebih sedikit daripada jumlah SMP yang mendapat akreditasi A dan B. Hal ini menunjukkan bahwa SMP telah mempersiapkan diri untuk dinilai sehingga target minimal dapat terakredtasi B. Hal ini didukung data SMP yang terakrditasi A pada tahun 2010 lebih banyak daripada sekolah yang terakreditasi B maupun C.

Pencapaian Standar Nasional untuk jenjang SMP disajikan pada Tabel 4.

Tabel 4. Pencapaian 8 SNP Untuk SMP

\begin{tabular}{|c|l|c|}
\hline No & \multicolumn{1}{|c|}{ Standar } & Pencapaian SMP \\
\hline 1 & Isi & 89,40 \\
\hline 2 & Proses & 90,99 \\
\hline 3 & Lulusan & 65,10 \\
\hline 4 & Ketenagaan & 80,27 \\
\hline 5 & Sarpras & 86,03 \\
\hline 6 & Pengelolaan & 94,63 \\
\hline 7 & Pembiayaan & 88,36 \\
\hline 8 & Penilaian & 92,99 \\
\hline & Rata-rata & 85,97 \\
\hline
\end{tabular}

Berdasarkan table 4 tersebut terlihat bahwa untuk SMP rata-rata pencapaian standar nasional pendidikan telah mencapai 85,97\% dari yang diharapkan. Pencapaian yang tertinggi pada standar pengelolaan $(94,63 \%)$ dan terendah dicapai pada standar lulusan $(65,10 \%)$. 
Pada jenjang SMP tujuh standar nasional telah dilaksanakan secara optimal namun demikian standar kompetensi lulusan juga masih belum dapat dicapai secara optimal.Pada SMP ini, standar kompetensi lulusan belum dapat dicapai secara optimal mengingat peserta didik SMP merupakan peserta didik yang wajib memperoleh pendidikan dasar tanpa kecuali bagi yang mampu maupun kurang mampu.

Secara Rasional 8 komponen standar nasional pendidikan tersebut telah mampu digunakan untuk mengukur kinerja sekola namun berdasarkan FGD ada beberapa masukan selain 8 standar nasional. Berdasarkan hasil diskusi terhadap kepala sekolah dapat dikemukakan bahwa, secara rasional delapan standar nasional pendidikan sudah cocok digunakan sebagai instrument untuk mengukur kinerja sekolah, karena sebagian besar komponen sekolah sudah ada dalam delapan standar nasional tersebut. Namun masih ada usulan untuk menambah, yaitu perlunya ada standar lingkungan sekolah, kesiswaan, dan pelayanan.Secara rinci menganai usulan tambahan standar nasional pendidikan dari kepala sekolah disajikan dalam Tabel 5 berikut.

Tabel 5. Usulan Tambahan Standar Nasional

\begin{tabular}{|l|l|c|}
\hline No & \multicolumn{1}{|c|}{ Usulan Tambahan SNP } & Persentase \\
\hline 1 & Lingkungan sekolah & $37 \%$ \\
\hline 2 & Pelayanan & $28 \%$ \\
\hline 3 & Kesiswaan & $35 \%$ \\
\hline
\end{tabular}

Berdasarkan Tabel 5 dan Gambar 1 terlihat bahwa hasil usulan yang terbanyak adalah menambah standar lingkungan sekolah dengan pencapaian 37\%, para kepala sekolah mengemukakan alasan bahwa menciptakan lingkungan sekolah yang nyaman dan berkualitas baik lingkungan fisik (bebas dari kebisingan, polusi) dan sosial (jauh dari pabrik, pasar, tempat perjudian, dll) dapat mendukung kelancaran kegiatan belajar mengajar dan konsentrasi belajar siswa. 


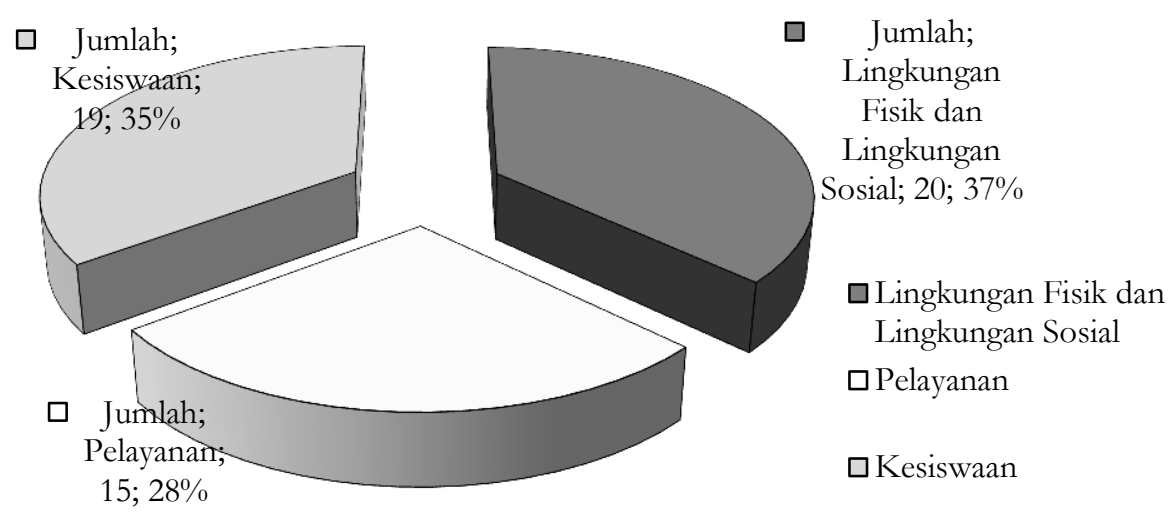

\section{Gambar 1. Persentase Usulan Tambahan Standar}

Usulan selanjutnya adalah penambahan standar kesiswaan sebanyak 35\%. Dalam Permendiknas No. 23/2006 telah dirumuskan Standar Kompetensi Lulusan (SKL) yang harus dicapai peserta didik, melalui proses pembelajaran berbagai mata pelajaran. Namun peserta didik sendiri belum distandarkan, masukan dari beberapa hasil diskusi sebaiknya peserta didik juga masukan dalam Standar nasional yang meliputi aspek perkembangan peserta didik adalah: (1) Landasan hidup religius; (2) Landasan perilaku etis; (3) Kematangan emosi; (4) Kematangan intelektual; (5) Kesadaran tanggung jawab sosial; (6) Kesadaran gender; (7) Pengembangan diri; (8) Perilaku kewirausahaan (kemandirian perilaku ekonomis); (9) Wawasan dan kesiapan karier; (10) Kematangan hubungan dengan teman sebaya.

Usulan berikutnya alah pada penambahan standar pelayanan yaitu sebanyak 28\%. Sekolah merupakan ujung tombak terdepan dalam pelayanan publik di lingkungan pendidikan. Dalam persoalan pendidikan anak, orang tua dan masyarakat selalu menginginkan agar anaknya mendapatkan pendidikan terbaik dan mendapatkan pelayanan yang prima. Oleh karena itu, sekolah haruslah responsif dalam menyikapi kemauan masyarakat tanpa mengorbankan efisiensi dan efektivitas penyelenggaraan sekolah. Salah satu cara yang dapat digunakan sekolah agar dapat melayani 
masyarakat dengan prima adalah kemauan untuk menggeser paradigma birokrasi yang lebih sibuk dengan urusan internal, menjadi berorientasi pada pelanggan sekolah. Sekolah diharapkan memposisikan pelanggan sebagai hal yang paling depan. Oleh sebab itu, pelanggan dipakai sebagai sasaran pencapaian tujuan.

Urutan prioritas dalam pemenuhan SNP diketahui berdasarkan korelasinya dengan standar proses. Hubungan enam standar nasional dengan standar proses ditunjukkan pada Tebel 6 berikut.

Tabel 6. $\quad$ Prioritas Pemenuhan Standar Nasional Pendidikan Untuk Meningkatkan Proses Pembelajaran Di SMP

\begin{tabular}{|l|l|l|l|}
\hline No & Korelasi Antar Standar & $\begin{array}{c}\text { Koefisien } \\
\text { Korelasi }\end{array}$ & $\begin{array}{l}\text { No. Prioritas } \\
\text { pemenuhan standar } \\
\text { untuk meningkatkan } \\
\text { proses pembelajaran } \\
\text { di SMP }\end{array}$ \\
\hline 1. & Isi (X1) dengan proses (X7) & 0,378 & 1 \\
\hline 2. & Ketenagaan (X2 dengan proses (X7) & 0,228 & 4 \\
\hline 3. & Sarpras (X3) dengan proses (X7) & 0,274 & 3 \\
\hline 4. & Pembiayaan (X4) dengan proses (X7) & 0,126 & 5 \\
\hline 5. & Pengelolaan (X5) dengan X7 & 0,121 & 6 \\
\hline 6. & Penilaian (X6) dengan proses (X7) & 0,301 & 2 \\
\hline
\end{tabular}

Berdasarkan Tabel 6 tersebut, maka untuk meningkatkan proses pembelajaran, prioritas yang dilakukan dapat diurutkan sebagai berikut.

1. Meningkatkan standar isi

2. Meningkatkan standar penilaian

3. Meningkatkan standar sarana dan prasarana

4. Meningkatkan standar ketenagaan

5. Meningkatkan standar pembiayaan

6. Meningkatkan standar pengelolaan 
Hubungan tujuan standar nasional dengan standar kompetensi lulusan ditunjukkan pada Tabel 7 berikut.

Tabel 7. Prioritas Pemenuhan Standar Nasional Pendidikan Untuk Meningkatkan Kompetensi Lulusan Di SMP

\begin{tabular}{|l|l|c|c|}
\hline No & Korelasi Antar Standar & $\begin{array}{l}\text { Koefisien } \\
\text { Korelasi }\end{array}$ & $\begin{array}{l}\text { No. Prioritas pemenuhan } \\
\text { standar untuk } \\
\text { meningkatkan kompetensi } \\
\text { lulusan di SMP }\end{array}$ \\
\hline 1. & Isi (X1) dengan lulusan (Y) & 0,289 & 5 \\
\hline 2. & $\begin{array}{l}\text { Ketenagaan (X2) dengan } \\
\text { lulusan (Y) }\end{array}$ & 0,337 & 4 \\
\hline 3. & $\begin{array}{l}\text { Sarpras (X3) dengan lulusan } \\
\text { (Y) }\end{array}$ & 0,405 & 3 \\
\hline 4. & $\begin{array}{l}\text { Pembiayaan (X4) dengan } \\
\text { lulusan (Y) }\end{array}$ & 0,162 & 6 \\
\hline 5. & $\begin{array}{l}\text { Pengelolaan (X5) dengan } \\
\text { lulusan (Y) }\end{array}$ & 0,007 & 7 \\
\hline 6. & $\begin{array}{l}\text { Penilaian (X6) dengan lulusan } \\
\text { (Y) }\end{array}$ & 0,483 & 2 \\
\hline 7. & $\begin{array}{l}\text { Proses pembelajaran (X6) } \\
\text { dengan lulusan (Y) }\end{array}$ & 0,429 & 1 \\
\hline
\end{tabular}

Berdasarkan Tabel 7 tersebut, maka untuk meningkatkan pemenuhan standar kompetensi lulusan, prioritas yang dilakukan dapat diurutkan sebagai berikut:

1. Peningkatan standar penilaian

2. Peningkatan standar proses pembelajaran

3. Peningkatan standar sarana dan prasarana

4. Peningkatan standar ketenagaan

5. Peningkatan standar isi

6. Peningkatan standar pembiayaan

7. Peningkatan standar pengelolaan 
Skala prioritas dalam meningkatkan pemenuhan delapan standar nasional pada SMP, dilihat dari korelasi antara variabel dalam standar nasional dengan standar proses dan kompetensi lulusan. Secara umum prioritas pertama untuk meningkatkan standar nasional pendidikan adalah meningkatkan pada standar isi baru meningkatkan standar-standar yang lain. Korelasi antara standar Isi dengan proses tertinggi adalah pada peningkatan kualitas standar isi $(0,378)$ dan yang terendah adalah pada peningkatan standar pembiayaan $(0,162)$.

SNP yang paling sulit dicapai disajikan pada Tabel 8.

Tabel 8. Urutan Kesulitan Dalam Mencapai Standar Nasional Pada SMP

\begin{tabular}{|l|l|c|c|}
\hline No & \multicolumn{1}{|c|}{ Standar } & $\begin{array}{l}\text { Tingkat Pencapaian } \\
\text { Untuk SMP }(\%)\end{array}$ & $\begin{array}{c}\text { Urutan Rangking } \\
\text { Kesulitan Mencapai }\end{array}$ \\
\hline 1 & Isi & 89,40 & 5 \\
\hline 2 & Proses & 90,99 & 6 \\
\hline 3 & Lulusan & 65,10 & 1 \\
\hline 4 & Ketenagaan & 80,27 & 2 \\
\hline 5 & Sarpras & 86,03 & 3 \\
\hline 6 & Pengelolaan & 94,63 & 8 \\
\hline 7 & Pembiayaan & 88,36 & 4 \\
\hline 8 & Penilaian & 92,99 & 7 \\
\hline & Rata-rata & 85,97 & \\
\hline
\end{tabular}

Standar nasional pendidikan yang paling sulit pada satuan Pendidikan SMP ditunjukkan pada tabel 8 berikut. Rata-rata pencapaian standar nasional untuk SMP adalah 85,97 \%. Standar nasional yang paling sulit dicapai dapat diurutkan sebagai berikut. Untuk SMP standar yang paling sulit adalah mencapai standar kompetensi lulusan (65,10\%), selanjutnya kesulitan berturut turut adalah standar ketengaan, sarana dan prasarana, pembiayaan, isi, proses, penilaian dan pengelolaan. Hal menunjukkan 
bahwa rata-rata kualitas lulusan untuk SMP yang masih rendah, sehingga memang tingkat kelulusan untuk SMP paling sulit untuk di capai hal ini dipengaruhi oleh motivasi anak masih kurang, kurangnya bimbingan orangtua selain itu juga dipengaruhi oleh letak geografis, keterjangkauan jarak, sulitnya sarana transportasi, daerah yang masyarakatnya agraris.

Kepuasan peserta didik terhadap pelayanan yang diberikan oleh setiap sekolah dikelompokkan berdasarkan status akreditasi sekolah. Hasilnya disajikan pada Tabel 9.

Tabel 9. Tingkat Kepuasan Pelayanan Pendidikan Pada SMP Berdasarkan Status Akreditasi Sekolah

\begin{tabular}{|c|c|c|}
\hline No & Status Akreditasi & $\begin{array}{c}\text { T Tingkat Kepuasan } \\
\text { Pelayanan }\end{array}$ \\
\hline 1 & A & $84,3 \%$ \\
\hline 2 & B & $83,3 \%$ \\
\hline 3 & C & $80,0 \%$ \\
\hline & Rata-rata & $82,6 \%$ \\
\hline
\end{tabular}

Penelitian tentang mutu sekolah juga diukur berdasarkan kualitas pelayanan yang diberikan. Dalam penelitian ini yang digunakan sebagai reponden SMP murid kelas 9, dengan jumlah responden 10 diambil secara random. Pengumpulan data menggunaakan instrumen kuesioner dengan skala 1 sd 4 . Angka 1 berarti pelayanan tidak memuaskan, angka 2 berarti pelayanan kurang memuaskan, angka 3 berarti pelayanan memuaskan dan angka 4 berarti pelayanan sangat memuaskan.

Hambatan-hambatan dalam pemenuhan Setiap Standar Nasional Pendidikan, dan Rasional Standar Nasional dikelompokkan menjadi delapan juga diidetifikasi. Hasilnya disajikan pada Tabel 10. 
Tabel 10. Hambatan-Hambatan dalam Pemenuhan SNP

\begin{tabular}{|c|c|c|c|}
\hline No & Aspek & Hambatan-hambatan & Usaha-usaha \\
\hline 1 & Kurikulum & $\begin{array}{l}\text { Guru belum mampu } \\
\text { membuat/menyusun } \\
\text { struktur kurikulum bagi } \\
\text { program pengembangan } \\
\text { diri, Kurikulum terlalu } \\
\text { luas, padat dan tinggi } \\
\text { tingkat kesukarannya, } \\
\text { kompetensi tim } \\
\text { pengembangan kurikulum } \\
\text { masih kurang }\end{array}$ & $\begin{array}{l}\text { Mengadaptasi } \\
\text { /menyesuaikan dengan } \\
\text { kurikulum mata pelajaran } \\
\text { reguler yang masih } \\
\text { mempunyai hubungan } \\
\text { dengan program } \\
\text { pengembangan diri, } \\
\text { Menyusun materi sendiri } \\
\text { yang dapat dicapai, } \\
\text { Meningkatkan kompetensi } \\
\text { tim pengembang } \\
\text { kurikulum melalui } \\
\text { workshop }\end{array}$ \\
\hline 2 & Proses & $\begin{array}{l}\text { Target rpp belum } \\
\text { terpenuhi, Pembelajaran di } \\
\text { kelas kadang terganggu } \\
\text { karena hal teknis }\end{array}$ & $\begin{array}{l}\text { Guru jaga/guru mapel } \\
\text { sejenis bertugas mengisi } \\
\text { jam-jam kosong, Perlu } \\
\text { persiapan teknis agar tidak } \\
\text { terganggu proses } \\
\text { pembelajaran }\end{array}$ \\
\hline 3 & $\begin{array}{l}\text { Pendidik dan } \\
\text { tenaga } \\
\text { kependidikan }\end{array}$ & $\begin{array}{l}\text { Guru sering terlambat, } \\
\text { kurang disiplin dalam } \\
\text { melaksanakan tugas, } \\
\text { Beban guru sangat banyak }\end{array}$ & $\begin{array}{l}\text { Mengatur jam mengajar, } \\
\text { pembinaan, Mengajukan } \\
\text { kekurangan guru UN pada } \\
\text { dinas pendidikan }\end{array}$ \\
\hline 4 & Lulusan & $\begin{array}{l}\text { Rata-rata nilai UN kurang } \\
\text { dari } 7,5 \text {, siswa yang } \\
\text { diterima di sekolah } \\
\text { unggulan baru } 15 \% \text {, Daya } \\
\text { serap siswa terhadap } \\
\text { materi pelajaran belum } \\
\text { optimal. }\end{array}$ & $\begin{array}{l}\text { Meningkatkan nilai UN } \\
\text { dengan menambah jam } \\
\text { bimbel dan try out } \\
\text { sekolah, usaha untuk } \\
\text { meningkatkan nilai UN, } \\
\text { Melaksanakan tes } \\
\text { diagnosik, try out, } \\
\text { remedial/pengayaan. }\end{array}$ \\
\hline
\end{tabular}




\begin{tabular}{|c|c|c|c|}
\hline No & Aspek & Hambatan-hambatan & Usaha-usaha \\
\hline 5 & Pembiayaan & $\begin{array}{l}\text { Menetapkan persentasi } \\
\text { masing-masing pos belanja } \\
\text { dari sumber yang berbeda- } \\
\text { beda, sekolah tidak } \\
\text { melakukan pungutan } \\
\text { bulanan sehingga } \\
\text { kekurangan biaya }\end{array}$ & $\begin{array}{l}\text { Kordinasi bendahara } \\
\text { sekolah secara periodik, } \\
\text { Membiayai sekolah } \\
\text { dengan menggunakan } \\
\text { dana bos }\end{array}$ \\
\hline 6 & Pengelolaan & $\begin{array}{l}\text { Program pembelajaran } \\
\text { berbentuk bilingual dan } \\
\text { kerjasama dengan lembaga } \\
\text { pendidikan internasional } \\
\text { belum maksimal }\end{array}$ & $\begin{array}{l}\text { Penerapan guru dalam } \\
\text { pembibingan kelas } \\
\text { ditingkatkan, kursus bhs. } \\
\text { Inggris lebih ditingkatkan, } \\
\text { sister school dengan } \\
\text { negara lain diadakan }\end{array}$ \\
\hline 7 & Penilaian & $\begin{array}{l}\text { Persepsi penilaian yang } \\
\text { dilakukan oleh pemerintah } \\
\text { dan pendidik masih } \\
\text { berbeda, tanpa melihat } \\
\text { proses di lapangan, UN } \\
\text { yang terlalu dini, tanpa ada } \\
\text { feedback, Penilaian sesuai } \\
\text { standar kompetensi lulusan } \\
\text { masih belum terlaksana } \\
\text { sepenuhnya }\end{array}$ & $\begin{array}{l}\text { Hasil penilaian oleh } \\
\text { pendidik hanya mengejar } \\
\text { target saja yang telah } \\
\text { ditetapkan oleh penilaian } \\
\text { dari pemerintah, } \\
\text { Dilaksanakan IHT dalam } \\
\text { membuat sistem penilaian } \\
\text { yang standar }\end{array}$ \\
\hline 8 & $\begin{array}{l}\text { Sarana dan } \\
\text { Prasrana }\end{array}$ & $\begin{array}{l}\text { Daya dukung untuk } \\
\text { pengembangan sarana } \\
\text { yang belum ada terutama } \\
\text { dalam mengakses } \\
\text { informasi dari luar, Alat } \\
\text { cetak atau printer dan alat } \\
\text { bantu administrasi masih } \\
\text { kurang }\end{array}$ & $\begin{array}{l}\text { Mengadakan hotspot dan } \\
\text { modem/flash untuk } \\
\text { mengakses informasi yang } \\
\text { lebih up to date } \\
\text { Pengadaan printer satu } \\
\text { set. Pengadaan laptop }\end{array}$ \\
\hline
\end{tabular}

528 - Jurnal Penelitian dan Evaluasi Pendidikan Tahun 16, Nomor 2, 2012 


\section{Simpulan}

1. Sebanyak $12 \%$ SMP telah layak mencapai standar nasional $>70-80 \%$ dari $100 \%$ yang diharapkan, dan $>80 \%$ yaitu $88 \%$

2. Rata-rata tingkat pemenuhan/ pencapaian standar nasional SMP diukur berdasarkan persentase lulusan bahwa, rata-rata persentase lulusan nasional untuk SMP/MTs pada tahun $2006=92,1 \%$, tahun $2007=93,34 \%$; tahun $2008=92,76 \%$; tahun $2009=95,09 \%$ dan tahun $2010=99,42 \%$. Pada jenjang SMP/MTs/SMPT, jumlah kelulusan meningkat 2,33\% dari tahun 2008 sedangkan pada tahun 2010 jumlah kelulusan meningkat 4,33\% dari tahun 2009 .

3. Jumlah SMP yang terakreditasi A tahun $2007=868$, tahun $2008=959$ dan tahun $2009=1856$. Jumlah yang terakreditasi B lebih banyak daripada $A$, dan yang yang terakreditasi $C$ lebih sedikit daripada A.

4. Pencapaian standar nasional pendidikan untuk SMP rata-rata pencapaian standar nasional pendidikan telah mencapai $85.97 \%$ dari yang diharapkan. Pencapaian yang tertinggi pada standar pengelolaan (94.63\%) dan terendah dicapai pada standar lulusan (65.10\%).

5. Delapan standar nasional yang digunakan sebagai instrumen untuk mengukur kinerja sekolah menengah pertama sudah rasional, karena sebagian besar sudah dapat digunakan untuk mengukur kinerja setiap komponen pendidikan. Namun bedasarkan diskusi dengan para kepala sekolah, terdapat penambahan jumlah komponen standar nasional yaitu standar lingkungan, kesiswaan dan pelayan.

6. Berdasarkan hubungan antar variabel yang ditemukan, maka untuk meningkatkan proses pembelajaran urutan prioritas yang perlu dilakukan adalah :

a. Meningkatkan kualitas standar isi $(0,378)$

b. Meningkatkan kualitas standar penilaian $(0,301)$

c. Meningkatkan kualitas standar sarana dan prasarana $(0,274)$

d. Meningkatkan kualitas standar ketenagaan $(0,228)$

e. Meningkatkan kualitas standar pembiayaan $(0,126)$

f. Meningkatkan kualitas standar pengelolaan $(0,121)$ 
Selanjutnya untuk meningkatkan pencapaian standar kompetensi lulusan, dapat dilakukan secara langsung tanpa melalui standar proses dengan urutan prioritas yang dilakukan adalah

a. Meningkatkan kualitas pencapaian penilaian $(0,483)$

b. Meningkatkan kualitas pencapaian proses pembelajaran $(0,493)$

c. Meningkatkan kualitas pencapaian standar sarana dan prasarna $(0,405)$

d. Meningkatkan kualitas pencapaian standar ketenagaan $(0,337)$

e. Meningkatkan kualitas pencapaian standar isi $(0,289)$

f. Meningkatkan kualitas pencapaian standar pembiayaan $(0,162)$

g. Meningkatkan kualitas pencapaian standar pengelolaan $(0,007)$

7. Standar nasional yang paling sulit dicapai dapat diurutkan sebagai berikut. Untuk SMP standar yang paling sulit adalah mencapai standar kompetensi lulusan $(65,10 \%)$, selanjutnya kesulitan berturut turut adalah standar ketengaan, sarana dan prasarana, pembiayaan, isi, proses, penilaian dan pengelolaan

8. Tingkat kepuasan pelayanan pendidikan pada SMP berdasarkan status akreditasi sekolah adalah $82,6 \%$

9. Hambatan-Hambatan dan Usaha-Usaha yang dilakukan dalam pencapaian standar nasional adalah sebagai berikut : a). Isi kurikulum: Guru belum mampu membuat / menyusun struktur kurikulum bagi program pengembangan diri, Kurikulum terlalu luas, padat dan tinggi tingkat kesukarannya, kompetensi tim pengembangan kurikulum masih kurang, Usaha: Mengadaptasi / menyesuaikan dengan kurikulum mata pelajaran reguler yang masih mempunyai hubungan dengan program pengembangan diri, Menyusun materi sendiri yang dapat dicapai, Meningkatkan kompetensi tim pengembang kurikulum melalui workshop, b). Proses: Target rpp belum terpenuhi, Pembelajaran di kelas kadang terganggu karena hal teknis, Usaha: Guru jaga/guru mapel sejenis bertugas mengisi jam-jam kosong, Perlu persiapan teknis agar tidak terganggu proses pembelajaran, c) Pendidik dan Tenaga Kependidikan: Guru sering terlambat, kurang disiplin dalam melaksanakan tugas, Beban guru sangat banyak, Usaha: Mengatur jam mengajar, pembinaan, Mengajukan kekurangan guru 
UN pada dinas pendidikan, d). Lulusan: Rata-rata nilai UN kurang dari 7,5 , siswa yang diterima di sekolah unggulan baru 15\%, Daya serap siswa terhadap materi pelajaran belum optimal, Usaha: Meningkatkan nilai UN dengan menambah jam bimbel dan try out sekolah, usaha untuk meningkatkan nilai UN, Melaksanakan tes diagnosik, try out, remedial/pengayaan, e). Pembiayaan: Menetapkan persentasi masingmasing pos belanja dari sumber yang berbeda-beda, sekolah tidak melakukan pungutan bulanan sehingga kekurangan biaya, Usaha: Kordinasi bendahara sekolah secara periodik, Membiayai sekolah dengan menggunakan dana bos, f). Pengelolaan: Program pembelajaran berbentuk bilingual dan kerjasama dengan lembaga pendidikan internasional belum maksimal, Usaha: Penerapan guru dalam pembibingan kelas ditingkatkan, kursus bhs. Inggris lebih ditingkatkan, sister school dengan negara lain diadakan, g). Penilaian: Persepsi penilaian yang dilakukan oleh pemerintah dan pendidik masih berbeda, tanpa melihat proses di lapangan, UN yang terlalu dini, tanpa ada feedback, Penilaian sesuai standar kompetensi lulusan masih belum terlaksana sepenuhnya, Usaha: Hasil penilaian oleh pendidik hanya mengejar target saja yang telah ditetapkan oleh penilaian dari pemerintah, Dilaksanakan IHT dalam membuat sistem penilaian yang standar, h). Sarana dan Prasarana: Daya dukung untuk pengembangan sarana yang belum ada terutama dalam mengakses informasi dari luar, Alat cetak atau printer dan alat bantu administrasi masih kurang, Usaha: Mengadakan hotspot dan modem/flash untuk mengakses informasi yang lebih up to date Pengadaan printer satu set. Pengadaan laptop

\section{Daftar Pustaka}

Depdiknas,.Undang-undang no 20 Tabun 2003 Tentang Sistem Pendidikan Nasional

Depdiknas. Peraturan Pemerintah no 19 tabun 2005 Tentang Standar Nasional Pendidikan 
Goetsch, Davis D L; Davis, Stanley B. 2006. Quality Management; Instroduction Total Quality Management for Production, Processing, and Service; Fift Edition; Pearson, Prentice Hall.

Nana Syaodih Sukmadinata. Dkk, Pengendalian Mutu Pendidikan Sekolah menengah: Konsep, Prinsip, dan Instrumen. Bandung: Refika Aditama, 2006), diakses dari pada tanggal 15 Mei 2011 dari http:/ /www.majalahpendidikan.com.

Sugiyono. 2006. Metode Penelitian Pendidikan, Pendekatan Kuantitatif, Kualitatif, R\&D, Alpha Beta. Bandung.

Republik Indonesia. Undang-Undang Dasar 1945. 